\title{
Impact of Service Environment for effective consumer behavior in Retails Industry with reference to Heritage Super Market
}

\author{
Mr. L Komagan ${ }^{\text {a }}$ Dr. Kiran Kumar Thoti ${ }^{\mathrm{b}}$ \\ ${ }^{\mathrm{a}}$ Research Scholar,Associate Professor, $\mathrm{KLH}^{\mathrm{b}}$ \\ ${ }^{\mathbf{a}, \mathbf{b}}$ Business School, Koneru Lakshmaiah Education Foundation Deemed to be University,Off Campus, Aziz Nagar, \\ Hyderabad- 500075 \\ a komagan_mba@yahoo.com, ${ }^{\mathrm{b}}$ kirankumar3561@gmail.com
}

Article History: Received: 10 November 2020; Revised 12 January 2021 Accepted: 27 January 2021; Published online: 5 April 2021

\begin{abstract}
Consumer behavior is dynamic and it needs to be evaluated by using scientific research methods. In this regard market research for Heritage had been conducted in this research work. Consumer behavior is complex subject and it is tough to predict the human internal thinking unless they express their opinions. Customers are sometimes loyal to the existing brands and some customers always show interest to adopt disruptive technology. Retailing business is more traditional in India and it had transformed in the past once decade. At the same time consumption also increased with growth of organized retailing business in India. The survey was conducted in selected Heritage super markets and parlous in Hyderabad. It was descriptive research \& Quantity research type and the samples were collect through convincing samples \& Simple random samples. The hypothesis was tested using the Correlations, Regression and ANOVA testing. There was a significant effect on the service environment and consumer behavior in the retail market.
\end{abstract}

Keywords: Marketing, Service Sector, Service Environment, Retail Industries

\section{Introduction}

Retailing business is the major contributor for gross domestic product (GDP) in India. It had generated millions of jobs both directly and indirectly. The population of India is the major advantage because of high demand for consumption for food products. Heritage is retailing brand and it known for its fresh and quality products. It offers food products, vegetables and household products. The product categories at Heritage had been constantly growing according to the needs and demands from the consumers. Market research helps in understanding the markets, consumers, suppliers and demand about selected products and services. It itself is broad term and organizations conduct market research to sustain in the business. In this regard the market research for Heritage had been conducted and this report describes about the consumer behavior and consumer intention towards Heritage products. The factor influencing consumer behavior and consumer intention are important and they need to be listed for creating appropriate marketing strategy. Recently Future Retail had purchase the stock in Heritage Food retail business. However Heritage brand is still being maintained and it helps the acquirer to convince the quality of food products.

Offering products at competitive prices had become primary objective of organized retailers in the modern world. Traditional retailers in unorganized sector offer products are max retail prices. But organizations have developed strategies and managing things to provide huge discounts for the customers. Elimination of middle men at various points in the channel management had created opportunity for giant retailing organizations. Majority of the organized retail stores are entering into partnership with suppliers and making bulk purchase of items. Online retailing had increased the cost of logistics and decreased the cost of products in the recent years.

When organizations or entrepreneurs enter into retail sector, they need to conduct market research. For example some customers are more likely to visit the stores directly for purchasing products whereas some customers would like to make purchase through online shopping. Purchase behavior of consumers varies according to the product category and occupation. Some customers enjoy shopping at malls and they get entertainment and joy when they get deals at the stores. Some consumers are so busy that they don't have time to physically visit the stores. Hence it leads to opportunity for online retail business.

\section{Need for Market Research}

Gathering information about the entire retailing industry is essential and it helps in conducting analysis in retailing sector. Some locations with potential business are having lack of organized retail stores whereas some 
place there are many organized retails stores but lack of potential demand. For overcoming all the issues, market research provides a direction for the entrepreneurs. Even existing organizations can growth much faster with marketing research.

\section{Review of Literature}

Sivapalan and jebarajakirthy (2017) had conducted a study on customer loyalty in retailing sector. Retail service quality (RSQ) is more important element for developing customer loyalty and it leads to customer retention. They have collected data from more than two thousand customers at three retail supermarkets and developed a structural model. They have developed a comprehensive mechanism to implement quality while providing quality service to customers. Priporas et al (2017) had suggested that smart technology must be adopted by retailing industry for better interaction with the customers during shopping. The technological advancements had provided opportunity to use smart technology either in online or offline shopping.

Hanaysha (2018) had conducted a survey with sample size of 278 who are customers in retailing outlets. The variables selected for collecting data are store environment, sales promotion, social media marketing, perceived value, corporate social responsibility and purchase decision. It is found that consumer purchase decision is strongly influenced by corporate social responsibility. Structural equation modeling technique was used to find the association between dependent and independent variables. Overall the perceived value of the product is another most important element which has impact on consumer decision making in retailing stores. Grewal et al (2020) had argued that retailing of services need to implemented with support of technology.

Mishra et al (2021) had described about omni-channel approach in retailing where customers are given service in various channels like internet, physical stores and mobile shopping. The behavior of consumers becomes positive when they get similar services in all the channels while shopping. It is also unexplored area in the field of marketing research and there is lot of scope for studying consumer behavior in this field. Fuentes-Blasco (2017) had taken variables like store equity, customer satisfaction and word-of-mouth while describing impact of technological innovation in retailing industry.

Bonetti et al (2018) mentioned about the implementation of virtual reality and augmented reality in retailing both in offline mode and online mode. The interdisciplinary research between information technology and retailing industry had increased a lot in the recent years. Now retailing organizations are looking different like entertainment places, discount stores and technology hubs. For example smart mirror had increased customer satisfaction and also less maintenance cost for retailers. Pantano and Gandini (2018) had described the integration of social media and digital technology for giving better shopping experience to customers. They have conducted qualitative study through semi-structured questionnaire and collected data from twenty individuals belonging to age group of 18 to 23 years.

Ambra-Fierro et al (2017) had surveyed about the influence of demographic variables in retail banking sector. When banks implement technology and provide service to customers then it leads to co-creation of value for the bank. It means satisfied customers create value to the organization through word-of-mouth communication. The gender and age are more important elements in retailing sector and it had been provide in retail banking. Ramanathan et al (2017) had made and enquiry in the field of retailing and found that social media reviews create customer loyalty. It further creates a strong message to the organization and helps to stay in the competitive business market. According to Nalla and Varalaxmi (2018) there is need for implementation of competitive compensation package for employee retention because they directly provide service to the customers.

\section{Research Objectives}

- To examining the factors influencing consumer behavior\& Customer intentions at Heritage.

- To find the association between demographic variables and consumer behavior at Heritage. 
Statement of Problem: The potential demand for retailing products had increased. But it is time for the existing business and organization to understand the consumer behavior and consumer intention. Market research is needed for understanding the problems of retailing sector. The analysis of consumer behavior is needed to create business strategies by organized retailers.

Scope of Research: Retailing sector is large and every individual is consumer of this industry. Food and household products are core products offered by retailing business. But in this study only market research from the perspective of consumer behavior is performed. This study is exclusively conducted by considering Heritage brand in retail sector in India.

Research Methodology:This study is combination of descriptive and quantitative research frameworks. The study is based on primary data and secondary data. Software like R, SPSS and Ms-Excel has been used for data analysis. The following research model shows the relationship between dependent and independent variables.

- Sample size: 250

- Sampling method: Simple random sampling

- $\quad$ Primary data: Structured closed ended questionnaire.

- Secondary data: Books, journals, magazines, internet and published company documents.

Source of Data:Structured questionnaire was share with the respondents who are existing customers of Heritage. A mall intercept approach was used to collect the opinion of customers towards Heritage. Secondary was collected from books, internet and journals. The questionnaire was prepared with demographic variables, shopping traits and constructs related to consumer behavior.

\section{Limitations}

- The research was limited to the boundaries of Hyderabad City.

- The results cannot be generalized because it is conducted by keeping Heritage as objective.

- The recent environmental variables like pandemic had not been considered during the study.

\section{Hypothesis Testing:}

H1: There is an impact of store environment on consumer behavior at Heritage

Result: The below table shows the regression test where consumer behavior is dependent variable and store environment is independent variable. The p-value for the store environment is less than 0.05 . Therefore $\mathrm{H} 1$ is accepted which means that there is positive impact of store environment on consumer behavior at Heritage supermarket.

Table 1: Regression Test Results: Coefficients ${ }^{\mathrm{a}}$

\begin{tabular}{|c|c|c|c|c|c|c|}
\hline \multirow{2}{*}{\multicolumn{2}{|c|}{ Model }} & \multicolumn{2}{|c|}{$\begin{array}{l}\text { Unstandardized } \\
\text { Coefficients }\end{array}$} & \multirow{2}{*}{\begin{tabular}{|c|}
$\begin{array}{c}\text { Standardized } \\
\text { Coefficients }\end{array}$ \\
Beta
\end{tabular}} & \multirow[t]{2}{*}{$\mathrm{t}$} & \multirow[t]{2}{*}{ Sig. } \\
\hline & & B & Std. Error & & & \\
\hline \multirow{5}{*}{1} & (Constant) & 1.292 & .283 & & 4.567 & .000 \\
\hline & Store Environment & .419 & .067 & .222 & 6.259 & .022 \\
\hline & Sales Promotion & .439 & .036 & .450 & 12.097 & .010 \\
\hline & Customer Relations & .287 & .032 & .313 & 8.847 & .023 \\
\hline & Perceived Value & .950 & .047 & .782 & 20.414 & .001 \\
\hline
\end{tabular}

a. Dependent Variable: Consumer Behavior

$\mathrm{H} 2$ : There is an impact of sales promotion on consumer behavior at Heritage

\section{Result:}

$\mathrm{H} 2$ is accepted because the p-value is less than benchmark value 0.05 . Hence sales promotions have positive influence on consumer behavior at Heritage supermarkets. The beta value for sales promotion is 0.450 which means the increase in sales promotion creates positive impact on consumer purchase behavior at Heritage supermarket.

H3: There is an impact of customer relations on consumer behavior at Heritage 
Result: $\mathrm{H} 3$ is accepted as per the p-value for customer relations which are independent variable. It is understood that consumer who are getting information about latest offers and promotion are developing positive consumer behavior at Heritage supermarkets. Heritage supermarket sends information for its members and regular customers through SMS and social media advertising. Heritage implements customer relationship management software for maintain the data of its customers.

H4: There is an impact of perceived value on consumer behavior at Heritage

Result: H4 is accepted because significant p-value for perceived value is less than benchmark value 0.05. Perceived value is about perception of customer about products for the money spent. When consumers feel perceived value then they become loyal for the brand and also for the organized retail stores. Hence dependent variable consumer behavior is positively influenced by the independent variable perceived value.

Regression Test Results: Co-efficientsa

\begin{tabular}{|c|c|c|c|c|c|c|}
\hline \multirow{2}{*}{\multicolumn{2}{|c|}{ Model }} & \multicolumn{2}{|c|}{$\begin{array}{l}\text { Unstandardized } \\
\text { Coefficients }\end{array}$} & \multirow{2}{*}{\begin{tabular}{|c}
$\begin{array}{c}\text { Standardized } \\
\text { Coefficients }\end{array}$ \\
Beta
\end{tabular}} & \multirow[t]{2}{*}{$\mathrm{t}$} & \multirow[t]{2}{*}{ Sig. } \\
\hline & & $\mathrm{B}$ & Std. Error & & & \\
\hline \multirow{3}{*}{1} & (Constant) & 2.352 & .241 & & 9.748 & .000 \\
\hline & Customer Relations & .685 & .038 & .737 & 17.863 & .010 \\
\hline & Perceived Value & .378 & .051 & .308 & 7.473 & .450 \\
\hline
\end{tabular}

a. Dependent Variable: Consumer Intention

H5: There is an impact of customer relations on consumer intention at Heritage

Result: H5 is accepted because benchmark value for customer relations in the above regression table is less than 0.05 . Hence customer relations at Heritage supermarket are having positive impact on consumer intention. It means sending message about deals and offers is creating positive intention among the consumers and they are becoming loyal to the organization.

H6: There is an impact of perceived value on consumer intention at Heritage

Result: H6 is rejected because significant p-value for perceived value is more than 0.05 . The p-value is for perceived value as per the above regression table is 0.450 . Therefore it can be stated that consumer perceived value is not influencing their intention towards Heritage stores. Consumers may think that it is responsibility of the organization to provide products with value for money.

H7: There is positive impact of consumer behavior on consumer intention at Heritage

Result: $\mathrm{H} 7$ is accepted because the p-value is 0.00 o which is less than benchmark value $(0.05)$, Hence consumer behavior at Heritage stores is creating positive impact on consumer intention towards Heritage stores.

Regression Test: Coefficientsa

\begin{tabular}{|c|c|c|c|c|c|}
\hline \multirow[t]{2}{*}{ Model } & \multicolumn{2}{|c|}{$\begin{array}{l}\text { Unstandardized } \\
\text { Coefficients }\end{array}$} & \multirow{2}{*}{\begin{tabular}{|c|}
$\begin{array}{c}\text { Standardized } \\
\text { Coefficients }\end{array}$ \\
Beta
\end{tabular}} & \multirow[t]{2}{*}{$\mathrm{t}$} & \multirow[t]{2}{*}{ Sig. } \\
\hline & B & Std. Error & & & \\
\hline (Constant) & 2.104 & .223 & & 9.431 & .000 \\
\hline Consumer Behavior & .398 & .059 & .394 & 6.750 & .012 \\
\hline
\end{tabular}

a. Dependent Variable: Consumer Intention

H8: There is an association between product category and consumer behavior at Heritage.

Result: As per the p-value in the one-way ANOVA table which is below; there exists and association product category and consumer intention. It means product category influence the consumer intention with regard to Heritage stores. 
One-way ANOVA: ANOVA

Consumer Intention

\begin{tabular}{|l|l|l|l|l|l|}
\hline & Sum of Squares & $\mathrm{df}$ & Mean Square & F & Sig. \\
\hline Between Groups & 109.922 & 3 & 36.641 & 52.765 & .031 \\
Within Groups & 170.825 & 246 & .694 & & \\
Total & 280.747 & 249 & & & \\
\hline
\end{tabular}

Heat map of correlations matrix

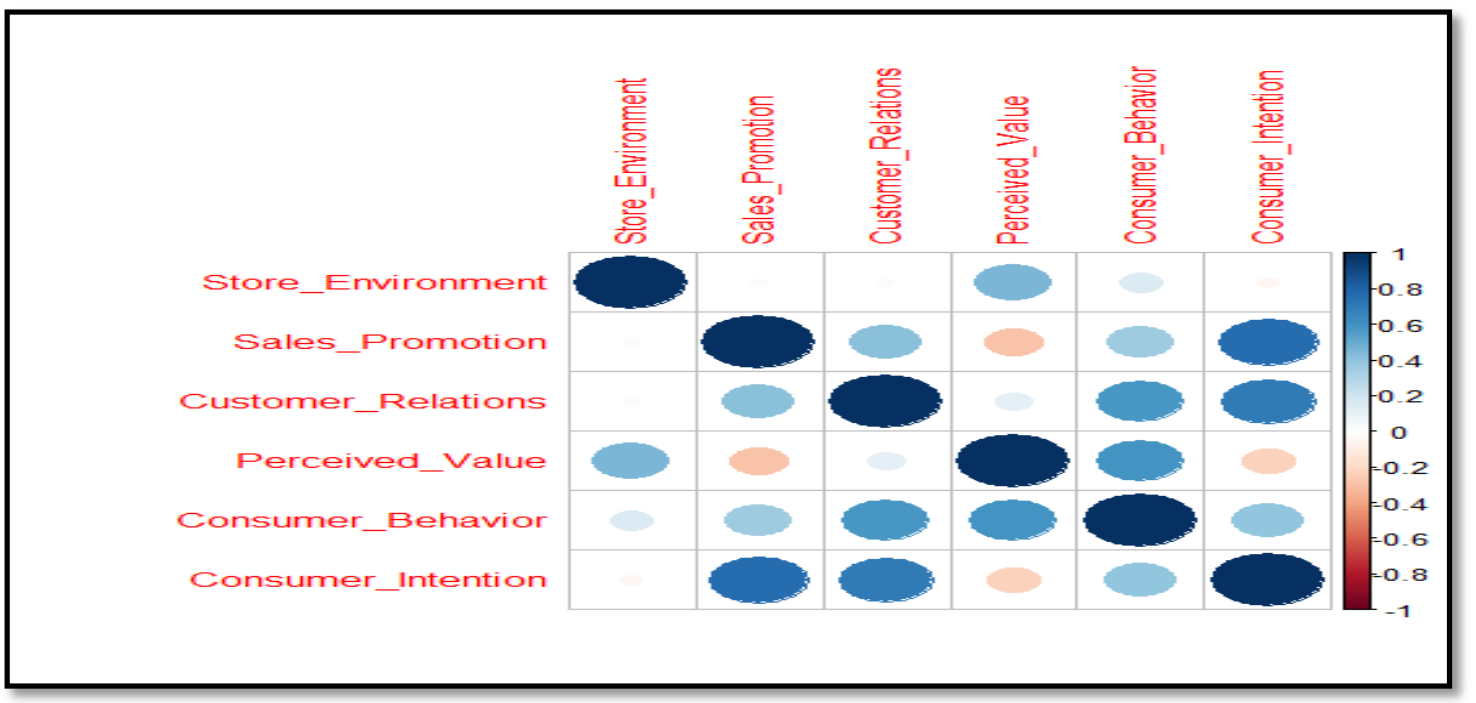

H9: There is correlation between perceived value and consumer intention

Result: As per the above heat map which had been develop using R software there exists correlation between consumer intention and perceived value. It means when consumers think positively about value for money at Heritage they develop positive intention towards shopping at the stores. Overall H9 is accepted as per the above heat map which is graphical output by using correlate package.

Decision Tree for Predicting Consumer Intention 
Figure 1: Decision Tree Consumer Intention

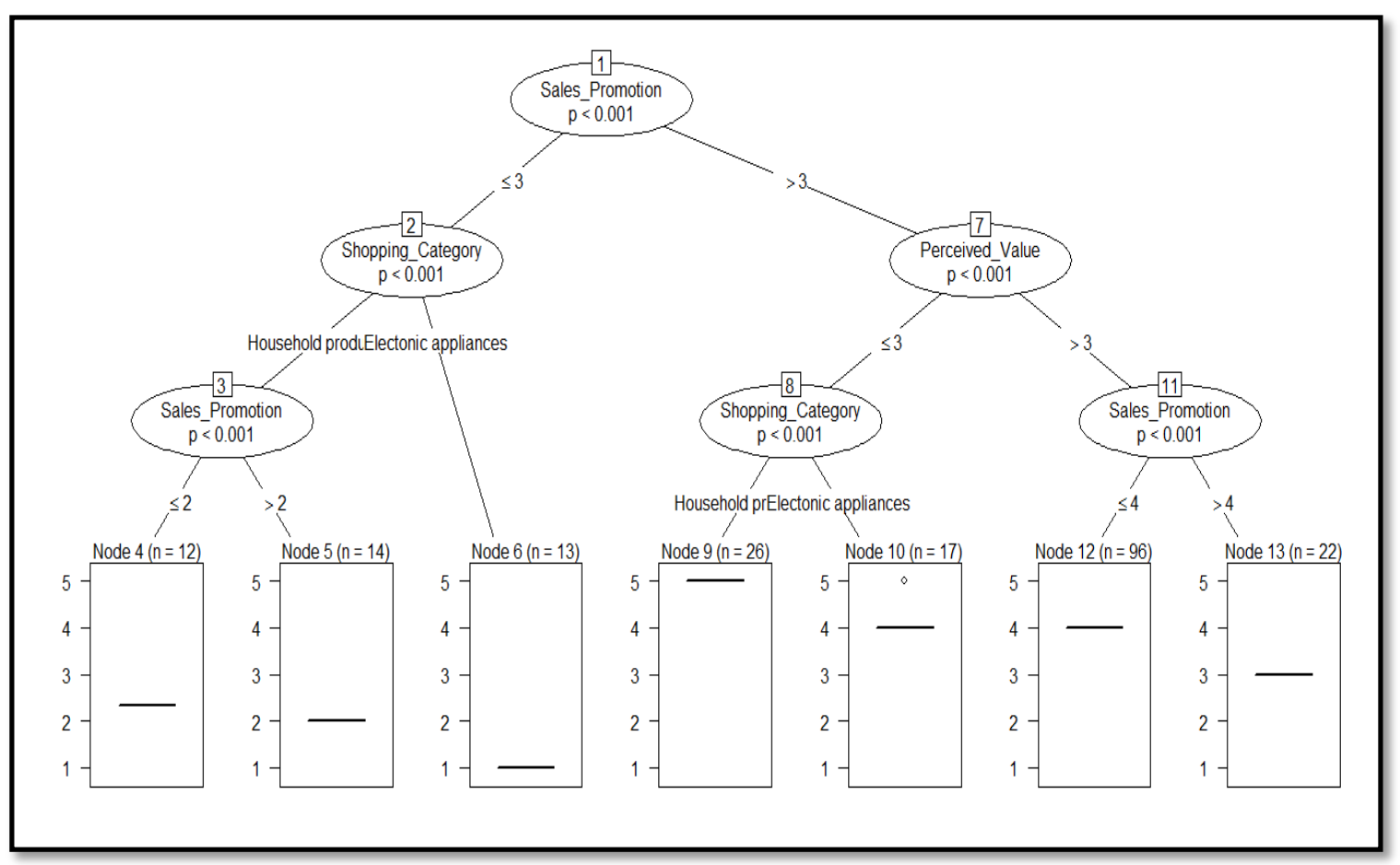

Response: Consumer Intention

Inputs: Gender, Age Group, Occupation, Shopping Frequency, Motive, Shopping Category, Product Category, Expected Benefit, Store Environment, Sales Promotion, Customer Relations, Perceived Value, Consumer Behavior

Interpretation: The above decision tree diagram had been developed using R software with party as package. The sales promotion is the major variables to anticipate the consumer intention towards shopping at Heritage.

Decision Tree for Consumer Behavior: Decision Tree Consumer Behavior

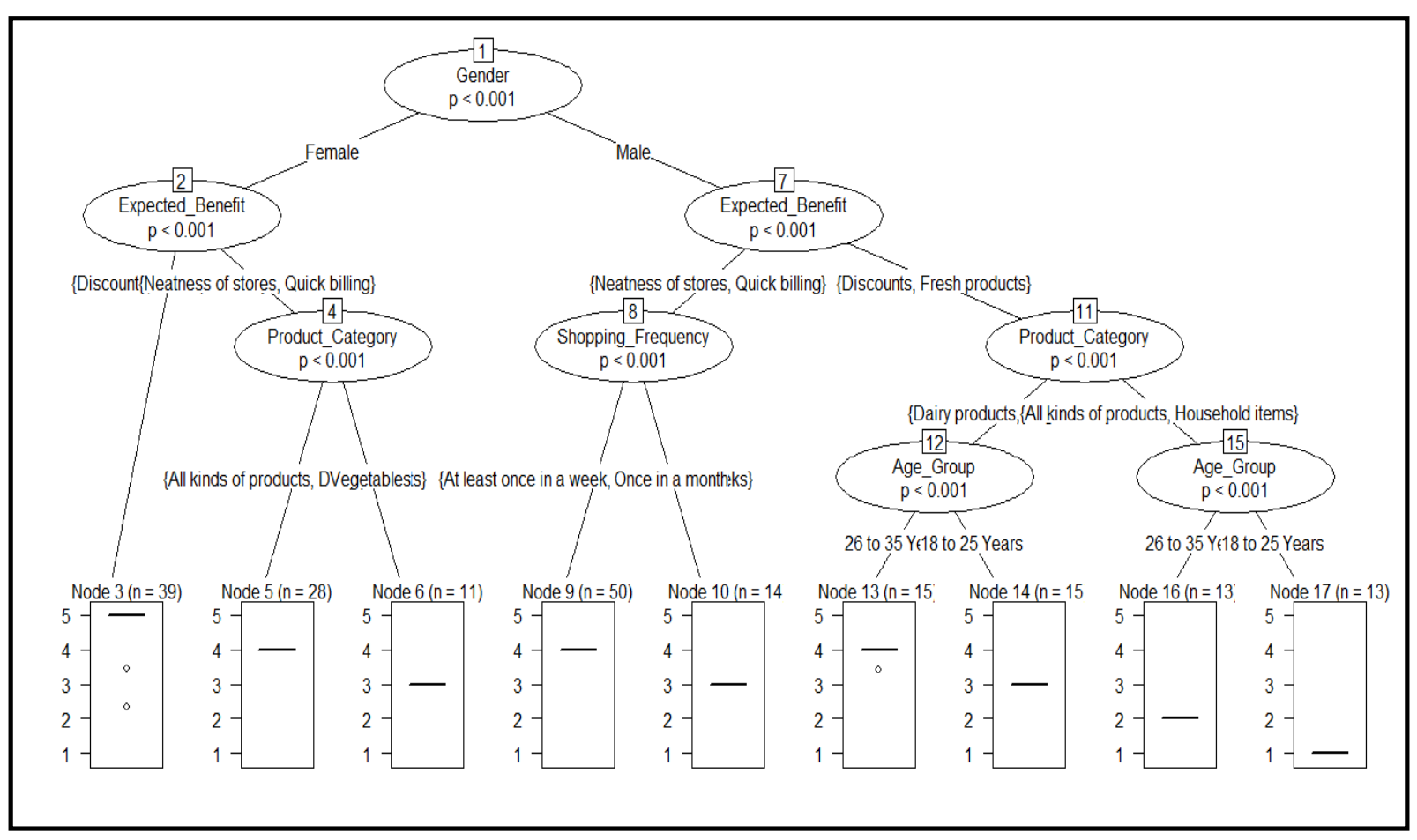

Response: Consumer Behavior 
Inputs: Gender, Age Group, Occupation, Shopping Frequency, Motive, Shopping Category, Product Category, Expected Benefit

Interpretation: When anticipating the consumer behavior, the major factor is gender of the respondent. The expected benefit and product category are next important variables to anticipate the consumer behavior at Heritage supermarket.

\section{Hypothesis Testing}

\begin{tabular}{lll}
\hline Hypothesis & Variables & Result \\
\hline H1 & Store Environment $\rightarrow$ Consumer Behavior & Accepted \\
H2 & Sales Promotion $\rightarrow$ Consumer Behavior & Accepted \\
H3 & Customer Relations $\rightarrow$ Consumer Behavior & Accepted \\
H5 & Perceived Value $\rightarrow$ Consumer Behavior & Accepted \\
H6 & Customer Relations $\rightarrow$ Consumer Intention & Accepted \\
H7 & Perceived Value $\rightarrow$ Consumer Intention & Rejected \\
H8 & Consumer Behavior $\rightarrow$ Consumer Intention & Accepted \\
H9 & Product Category $\leftarrow \rightarrow$ Consumer Intention & Accepted \\
\hline
\end{tabular}

8. Findings

$>$ Heritage stores are widely recognized for its fresh products.

$>$ Heritage is brand for quality food products and dairy products.

$>$ Heritage gives membership for its regular customers.

$>\quad$ There is high customer retention at Heritage and they are valued through membership cards.

$>$ At Heritage a minimum ten percent discounts is given to their customer with membership cards.

$>$ Consumer behavior at Heritage is positive influenced by sales promotions and store environment.

$>$ A heritage store gives impression of green color which is again symbolic to farm and healthy products.

$>$ Heritage maintains healthy customer relations and communicates with them through various kinds of media.

$>$ Heritage had given quality products even during the recent crisis pandemic.

$>$ Gender and sales promotion are important variables to anticipate the positive consumer behavior at Heritage.

$>$ Consumer intention at Heritage can be anticipated through expected benefits by its customers.

\section{Suggestions}

- Now it is time for Heritage to provide home delivery services.

- Heritage should aggressively invest in expansion.

- Due to lack of proximity many customer are shopping at alternative stores instead of Heritage.

- Heritage should become land mark wherever it is located.

$\circ \quad$ Heritage should decrease its operational cost by entering into strategic partnership with suppliers.

- Heritage should adopt franchise strategy and increase its presence in second and third tier cities.

- Heritage should implement Omni channel presence to keep in touch with the members.

- Irrespective of membership cards, Heritage should give minimum discounts to al the consumers.

○ Heritage should increase its economies of scale so that price of its dairy products can be low.

\section{Conclusion}

Heritage supermarket is branded company in retailing sector with its origin in India. It had various branches in prime locations. Vegetables and dairy products are widely remembered by its customers when shopping or thinking about Heritage supermarket. The growth of population and awareness about need for healthy food creates potential demand for Heritage food products. Discounts and proximity are primary demands for consumers in retailing industry. At present Heritage had been providing healthy food to people in metro locations but in future it need to expand to developing smart cities.

Recently government had selected some hundred cities in India as a part of smart city project. Now Heritage should expand to those smart cities and grab the opportunity of business. Consumer behavior may be dynamic for variety of products but with regard to food and health they always follow a consistent pattern and adopt a particular menu. Heritage is known for its food products targeted to children and young adults. The growth of Heritage is also strong from the perspective of its performance in stock market. 
Pandemic had given opportunity for retailing organizations to provide immunity food and fresh food. The pandemic had made people to invest more for food products and maintain healthy life. The increase in demand for honey, spices and dry fruits had increased the scope for business in retailing sector. Overall there is bright future for Heritage foods and retailing sector in India at large..

\section{References}

Bonetti, F., Warnaby, G., \& Quinn, L. (2018). Augmented reality and virtual reality in physical and online retailing: A review, synthesis and research agenda. Augmented reality and virtual reality, 119-132.

Cambra-Fierro, J., Perez, L., \&Grott, E. (2017). Towards a co-creation framework in the retail banking services industry: Do demographics influence?. Journal of Retailing and Consumer Services, 34, 219-228.

FuentesBlasco, M., MolinerVelázquez, B., ServeraFrancés, D. and GilSaura, I. (2017), "Role of marketing and technological innovation on store equity, satisfaction and word-of-mouth in retailing", Journal of Product \& Brand Management, Vol. 26 No. 6, pp. 650-666.

Grewal, D., Hulland, J., Kopalle, P. K., \&Karahanna, E. (2020). The future of technology and marketing: a multidisciplinary perspective, 48, 1-8.

Hanaysha, J.R . (2018), "An examination of the factors affecting consumer's purchase decision in the Malaysian retail market", PSU Research Review, Vol. 2 No. 1, pp. 7-23.

Mair, J., \& Reischauer, G. (2017). Capturing the dynamics of the sharing economy: Institutional research on the plural forms and practices of sharing economy organizations. Technological Forecasting and Social Change, 125, 11-20.

Mishra, R., Singh, R. K., \&Koles, B. (2021). Consumer decision-making in Omnichannel retailing: Literature review and future research agenda. International Journal of Consumer Studies, 45(2), 147-174.

Nalla, B., \&Varalaxmi, P. (2018). Human resource management practices in organized retailing-A stydy of select retailers. South Asian Journal of Marketing \& Management Research, 8(7), 15-28.

Pantano, E., \&Gandini, A. (2018). Shopping as a "networked experience": an emerging framework in the retail industry. International Journal of Retail \& Distribution Management, 46(7), 690-704.

Priporas, C. V., Stylos, N., \& Fotiadis, A. K. (2017). Generation Z consumers' expectations of interactions in smart retailing: A future agenda. Computers in Human Behavior, 77, 374-381.

Ramanathan, U., Subramanian, N., \& Parrott, G. (2017). Role of social media in retail network operations and marketing to enhance customer satisfaction. International Journal of Operations \& Production Management, 37(10), 105-123.

Sivapalan, A. and Jebarajakirthy, C. (2017), "An application of retailing service quality practices influencing customer loyalty toward retailers", Marketing Intelligence \& Planning, Vol. 35 No. 7, pp. 842-857.

Wilson, A., Thompson, T. L., Watson, C., Drew, V., \& Doyle, S. (2017). Big data and learning analytics: Singular or plural?. First Monday, 22(4).

Shankar, C., \& Thoti, K. K. (2020). CUSTOMER AWARENESS ON FOREX EXCHANGE CURRENCY ACTIVITIES IN INDIA WITH REFERENCE TO SOUTH ANDHRA PRADESH (RAYALASEEMA) LOCATION. Journal of Critical Reviews, 7(6), 2089-2096.

Sankar, O. S. S., \& Thoti, K. K. (2020). CUSTOMER PREFERENCES FOR SELECTING THE DIARY PRODUCTS IN COVID 19 CIRCUMSTANCE WITH REFERENCE TO ANDHRA PRADESH. Journal of Critical Reviews, 7(5), 2022-2027.

Thoti, K. K., \& Saufi, R. B. A. (2016). Empirical Study on Work Life Integration Practices in Electronic Industry. International Journal of Research in Economics and Social Sciences (IJRESS), 6(11).

Thoti, K. K. (2018). Impact of Stress on Employees Working in Andhra Pradesh South Power Distribution Limited. Sumedha Journal of Management, 7(3), 40-51.

Thoti, K. K. (2018). AN EMPIRICAL STUDY ON PAYSCALE MEASURMENT PRACTICES IN HOSPITALS SECTOR. NOLEGEIN-Journal of Human Resource Management \& Development, 38-42.

Thoti, K. K. (2016). Intervention of job stress and employee morale on organizational culture and employees' job efficiency (Doctoral dissertation, Universiti Malaysia Kelantan).

Thoti, K. K., \& Vyshnavi, P. A Study on Digital Marketing Strategy Building for Teachonapp. Com.

Thoti, K. K., Sarma, M. D. R. L., \& Kumar, M. G. S. (2020). Motivating Students \& Teachers In Higher Education With Reference To Pandemic Situations. PalArch's Journal of Archaeology of Egypt/Egyptology, 17(9), 1244-1249.

Thoti, K. K., \& Saufi, R. A. (2015). Organization Culture Influence the Job Stress in Information Technology Industries in Bangalore (India). International Journal of Entrepreneurship and Development Studies, 3(1), 4962.

Thoti, K. K. GRIEVANCE SETTLEMENT SYSTEM IN SMALL SCALE POLYMERS INDUSTRIES. Primax International Journal of Commerce And Management Research, 82. 